\title{
Does richness of Oligochaeta (Annelida) follows a linear distribution with habitat structural heterogeneity in aquatic sediments?
}

\author{
Flávio H. RAGONHA, ${ }^{1 *}$ Alice M. TAKEDA ${ }^{2}$ \\ ${ }^{1}$ Programa de Pós-Graduação em Ecologia de Ambientes Aquáticos Continentais, Universidade Estadual de Maringá, Av. Colombo \\ 5790, 87020-900 Maringá - PR, Brazil; ${ }^{2}$ Universidade Estadual de Maringá/ DBI/ NUPELIA/PEA. Av. Colombo 5790, 87020-900 \\ Maringá - PR, Brazil
}

\begin{abstract}
Sediment of aquatic environments supports several local communities, among them aquatic invertebrates. Habitat structural heterogeneity in sediments of aquatic ecosystems is related to a number of factors, including variability in the particle size of the substrate and availability of different food resources, the two structures that comprise the aquatic sediment. These structures are necessary for the stability of zoobenthic community, including the Oligochaeta assemblage, favoring richness as habitat heterogeneity increases. To analyze the habitat structural heterogeneity, we use these following structures: granulometric composition and organic matter composition, and we tested these structures together (habitat heterogeneity) and separately (granulometric and organic matter heterogeneity). This study investigated the relationship between habitat structural heterogeneity and richness of the Oligochaeta assemblage. We hypothesized that there is a positive linear relationship between habitat structural heterogeneity and richness of Oligochaeta, and predicted that the granulometric composition is more important than organic matter composition for increasing richness. There was no linear relationship between Oligochaeta richness and habitat heterogeneity; but the analysis showed an asymmetric triangular dispersion pattern, being granulometric heterogeneity more important than organic matter heterogeneity for richness of Oligochaeta. These results indicated that habitat structural heterogeneity was beneficial for richness of Oligochaeta until certain threshold and after this, the relationship between structural heterogeneity of habitats and richness of Oligochaeta is negative with decrease of diversity due to the filling of interstitial spaces which gradually reduces the ability to colonize these habitats.
\end{abstract}

Key words: neotropical, invertebrates, asymmetrical distribution, aquatic environments, type of sediments, organic matter composition.

Received: May 2013. Accepted: October 2013.

\section{INTRODUCTION}

Heterogeneity is defined as the complexity and/or variability of the properties of a system in space and/or time (Li and Reynolds, 1995). The term habitat structure refers to the physical structure and space serving as a support for the communities of plants and animals (McCoy and Bell, 1991), and these are considered important factors for ecological diversity (McArthur and McArthur, 1961). Habitat structure has an important role in determining species diversity (Bell et al., 1991), generally resulting in a linear relationship between species diversity and habitat structure (McArthur and McArthur, 1961; Rosenzweig and Winakur, 1969). However, some studies have found that this relationship may not always be linear for all communities (Whittaker, 1960; Magurran, 1988). In aquatic habitats the structural heterogeneity of sediments is related to a variety of factors such as variability of particle size (Brown, 2003) and availability of different food resources, as organic matter (Schwindt et al., 2001; Da Rocha et al., 2006). Variations in both particle size and food resource are often linked to presence of other organisms associated with these habitats (Jackson et al., 2008; Buschbaum et al., 2009). Habitat heterogeneity is a key factor enhancing the stability of communities, such as macroinvertebrates in environments exposed to great disturbances (Mykra et al., 2011). The importance of granulometric and organic matter compositions on benthic community is widely known in literature (Buss et al., 2004; Costa and Melo, 2008; Tokeshi and Arakaki, 2011). Benthic communities often exhibit preferences for certain substrates and particle sizes (Arakaki and Tokeshi, 2005; Rae, 2004). The substrates not only represent the habitat but also food resource for many organisms, then relationship of benthic organisms with grain size of sediment can be complex. In general, high richness tends to be associated with the diversity of particle sizes (Etter and Grassle, 1992). Oligochaeta is one of the most abundant groups among benthic invertebrates (Takeda, 1999; Ezcurra de Drago et al., 2005), recorded in almost all freshwater environments, and also in various neotropical floodplain environments as the Paraná River floodplain (Stevaux and Takeda, 2002; Takeda and Fujita, 2004; Behrend et al., 2009). Oligochaeta represent an excellent tool in studies of sediment morphological changes because the life cycle of these organisms are fully aquatic and also they have the ability to penetrate into sediments (Lafont et al., 
2007). Many species of Oligochaeta have direct relation with the size of the particles, thus differences in granulometric composition of sediment may influence the richness. In general, the sediments of aquatic ecosystems may be composed by pebbles, granules, very coarse sandy, coarse sandy, medium sandy, fine sand and very fine sandy accord to the habitat (Ezcurra de Drago et al., 2005; Behrend et al., 2009; Ragonha et al., 2013). Another factor that highly influences the richness of Oligochaeta are the different compositions of organic matter that are food for these annelids, and accordance the species can feed from coarse particulate organic matter or extremely small (Marchese, 1987; Marchese et al., 2002; Behrend et al., 2009). Thus habitats where there are heterogeneity of both structures as particle size and organic matter the higher colonization of different species in this habitats (Rae, 2004; Arakaki and Tokeshi, 2005).

Many studies have been conducted on increasing structural variability and its relationship to biological diversity using macrophytes (Dibble et al., 2006). Researchers also found that an increase in structural diversity causes also positive richness of fish (Harrel and Dibble, 2001; Agostinho et al., 2007) and in invertebrates (Rennie and Jackson, 2005; Thomaz et al., 2008; Mormul et al., 2011). However, investigations into sediment structural variations (particle size distribution and organic matter), as structural heterogeneity, in freshwater habitats are needed, in order to determine patterns of diversity and distribution, which have not be consolidated yet.

The objective of this study was to investigate until what point the increase in structural heterogeneity in benthic habitats (granulometric composition and matter organic composition) positively influenced richness of Oligochaeta on neotropical floodplain. We tested the hypothesis that exist linear relationship between habitat structural heterogeneity and richness of Oligochaeta, and our prediction is that the granulometric composition is more important than organic matter composition for $\alpha$-diversity.

\section{METHODS}

\section{Study area}

This study was conducted in the Upper Paraná River floodplain (Paraná, Brazil). The sampling area stretched from cities Três Lagoas (Mato Grosso do Sul, Brazil) to Guaíra (Paraná, Brazil), between the Porto Primavera and Itaipu dams, approximately $230 \mathrm{~km}$ and cover an area of 526,752 ha (Souza Filho and Stevaux, 1997). Samples were collected at 12 stations, grouped into three subsystems, the Paraná, Ivinhema and Baía (Fig. 1).

The Paraná subsystem consists of the Paraná River and associated floodplain lakes. The stretch of this river that was studied presents a braided channel, with mean current flow relatively high, varied width and extensive island
(Pauleto et al., 2009). In this stretch the river has an average depth of $4.0 \mathrm{~m}$ and could reach $15.0 \mathrm{~m}$ (Thomaz et al., 1992). In this subsystem, samples were collected in Paraná subsystem comprised by stations of sampling the Paraná

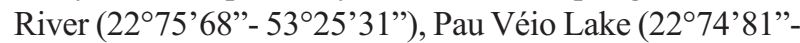
$\left.53^{\circ} 25^{\prime} 62^{\prime \prime}\right)$, Garças Lake (22 $\left.72^{\prime} 51^{\prime \prime}-53^{\circ} 21^{\prime} 67^{\prime \prime}\right)$, and Osmar Lake (22 $\left.77^{\prime} 40^{\prime \prime}-53^{\circ} 33^{\prime} 22^{\prime \prime}\right)$. Ivinhema subsystem consists of Ivinhema River as the main channel, which is one of main tributaries situated on the right bank of the Paraná River (Pauleto et al., 2009). It is connected to Paraná River through Ipoitã Channel (Thomaz et al., 1992). In this subsystem, samples were collected in Ivinhema River (22 $\left.82^{\prime} 86^{\prime \prime}-53^{\circ} 56^{\prime} 61^{\prime \prime}\right)$, the Ipoitã Channel

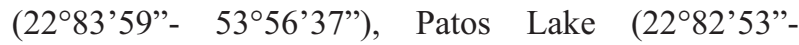
$\left.53^{\circ} 55^{\prime} 50^{\prime \prime}\right)$, and Ventura Lake (22 $\left.85^{\prime} 65^{\prime \prime}-53^{\circ} 60^{\prime} 02^{\prime \prime}\right)$.

The Baía subsystem includes the Baía River and connects to Paraná River through a channel its lower stretch (Baía Channel) and connected to Ivinhema River through Curutuba Channel (Pauleto et al., 2009). Baía River, a sinuous channel, with lentic characteristic, presents varied width, a mean depth of $3.2 \mathrm{~m}$, low declivity and low current flow and is directly influenced by the hydrological regime of Paraná River (Thomaz et al., 1992). In this subsystem, samples were collected in Baía River $\left(22^{\circ} 72^{\prime} 31^{\prime \prime}\right.$ $\left.53^{\circ} 29^{\prime} 04^{\prime \prime}\right)$, the Curutuba Channel (22 $\left.75^{\prime} 32^{\prime \prime}-53^{\circ} 35^{\prime} 85^{\prime \prime}\right)$,

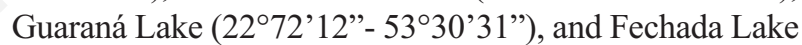
(22 $\left.71^{\prime} 19^{\prime \prime}-53^{\circ} 27^{\prime} 85^{\prime \prime}\right)$.

\section{Sampling}

Samples were collected in February, June, September and November 2008. In all environments right margin $(\mathrm{RM})$, left margin (LM) and center (CE) region were sampled. At each region, four samples were taken, three for biological analysis and one for assessment of habitat structural heterogeneity (granulometric and organic matter compositions), using a Petersen grab modified $\left(0.0345 \mathrm{~m}^{2}\right)$.

The collected material was placed in gallons and washed through a system of screens varying in mesh size (2.0-1.0 and $0.2 \mathrm{~mm}$ ). The material retained in the $0.2 \mathrm{~mm}$ screens was fixed with $80 \%$ alcohol and sorted under stereomicroscope. Oligochaeta were identified under optical microscope, in accordance with the identification keys of Brinkhurst and Jamieson (1971), Righi (1984), and Brinkhurst and Marchese (1991).

\section{Environmental variables}

The sediments were classified into different size classes using the scale of Wentworth (1922), while an estimation of organic matter was obtained by burning $20 \mathrm{~g}$ dry sediment in an oven at $560^{\circ} \mathrm{C}$ for about $4 \mathrm{~h}$. Water levels of Paraná River in 2008 were provided by Research Nucleus in Limnology, Ichthyology and Aquaculture (NUPELIA). The laboratory of Basic Limnology of NU- 
PELIA/UEM provided the environmental variables: depth $(\mathrm{m})$, temperature $\left({ }^{\circ} \mathrm{C}\right)$, electric conductivity $(\mathrm{ms} / \mathrm{cm}), \mathrm{pH}$, and dissolved oxygen $(\mathrm{mg} / \mathrm{L})$.

\section{Abiotic analysis}

In order to establish levels of habitat heterogeneity, values were calculated using the Shannon-Wiener index for each component of sediment (granulometric and organic matter compositions), and was verified the relationship this components together and separately. The Shannon-Wiener index was chosen as it is considered to best represent the habitats structural heterogeneity. This index takes into account the number of different sizes of particles separated by the sieves, and the equitability of different particle sizes.

To verify the influence of abiotic variables, other than granulometric and organic matter compositions, we used a principal component analysis (PCA), using PC-ORD 5.0 software (McCune and Mefford, 1999). Axes were retained for interpretations according to the broken-stick criteria. The variables used in the ordination were depth (m), $\mathrm{pH}$, temperature $\left({ }^{\circ} \mathrm{C}\right)$, conductivity $(\mathrm{ms} / \mathrm{cm})$, and dissolved oxygen $(\mathrm{mg} / \mathrm{L})$. We subsequently performed an analysis of variance (ANOVA), with the PCA axes scores retained for interpretation, to examine whether there were any differences between the sampling.

\section{Biotic analysis}

In our investigations, the same pattern using richness, Shannon-Wiener and Margalef indices were verified, therefore our results were not subjected to the effects of organism abundance and were chosen by richness. In

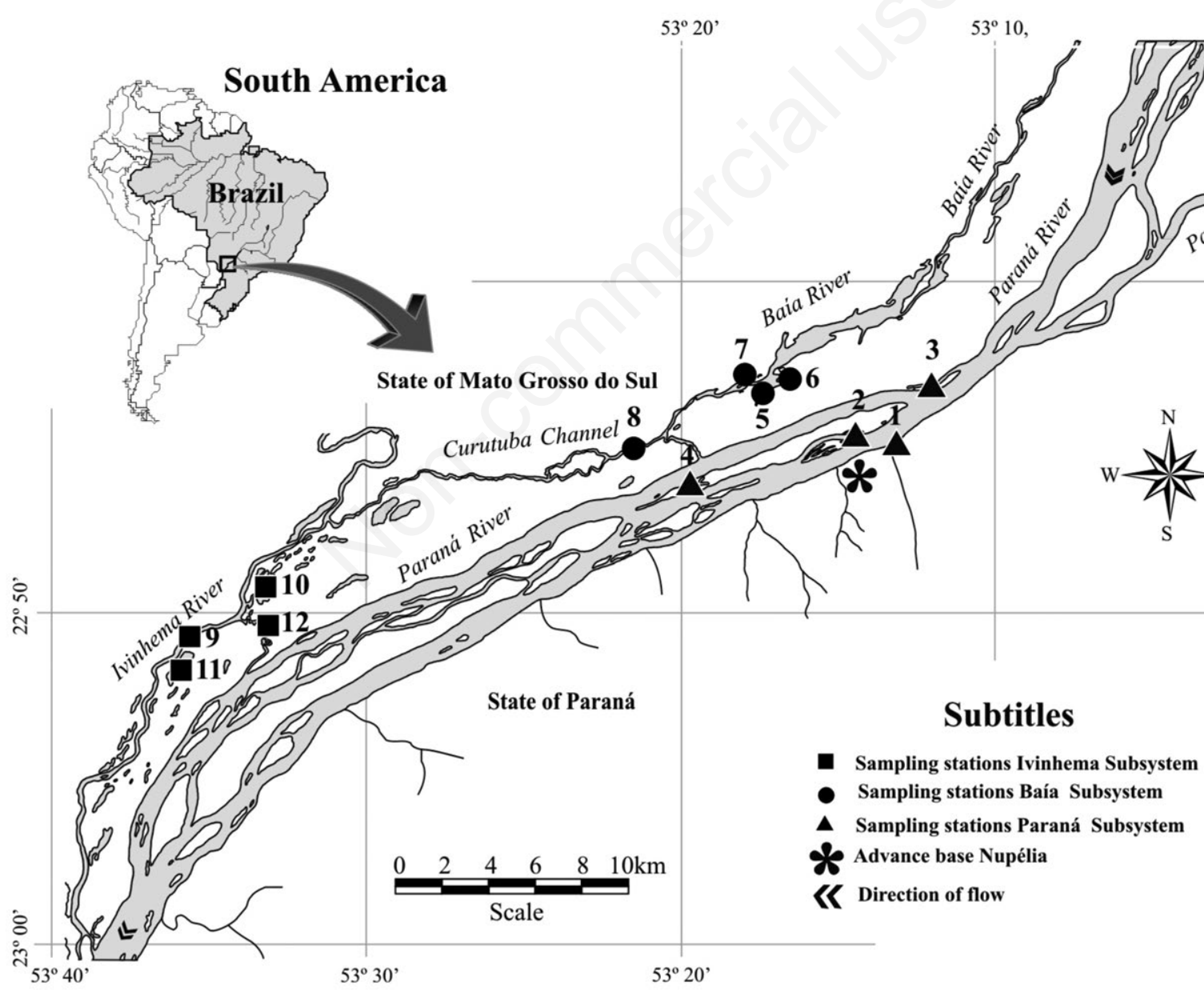

Fig. 1. Sampling stations of the Paraná River floodplain. 1, Paraná River (main channel); 2, Pau Véio Lake (lake with connection); 3 , Garças Lake (lake with connection); 4, Osmar Lake (lake isolated); 5, Baía River (main channel); 6, Fechada Lake (lake isolated); 7, Guaraná Lake (lake with connection); 8, Curutuba Channel (secondary channel); 9, Ivinhema River (main channel); 10, Patos Lake (lake with connection); 11, Ventura Lake (lake isolated); 12, Ipoitã Channel (secondary channel). 
order to assess the relationship between habitat structural heterogeneity and richness of Oligochaeta, we performed simple linear regression analysis, and analyzed separate structure (granulometric and organic matter compositions) to verify the affected response (richness). The analysis was performed using Statistica 7.1 software. The dominance index was calculated according to Kownacki (1971), by the given formula $d=\left(Q .100 / \sum Q\right) * f$, where Q is the mean number of specimens of species examined in the investigated series of samples; $\sum Q$ is the sum of the mean quantities of specimens of all species and $f$ is the frequency calculated from the ratio $n / N$, where $n=$ number of samples representing the species investigated, $\mathrm{N}=$ number of samples in the series.

Possible patterns for relationship between richness of Oligochaeta and habitat structural heterogeneity (granulometric and organic matter compositions) were tested (structures together and separately), according to the null model, using the EcoSim v. 7.71 software (Gotelli and
Entsminger, 2004) in order to test the existence of relationship in form of envelope restrictions: analysis of dispersion and triangular envelope. According to this model, the envelope constraint is defined initially by connecting the points Xmax, Ymin, and Ymax Xmedian and Xmin, Ymin, and Ymax and Xmax are only maximum for variables $\mathrm{X}$ and $\mathrm{Y}$. Xmin is only minimum for the variables $\mathrm{X}$ and $\mathrm{Y}$, and $\mathrm{X}$ median is the median of $\mathrm{X}$ (structural heterogeneity of habitat, respectively) (Gotelli and Entsminger, 2004). In this study, 5000 randomizations were used for this test.

\section{RESULTS}

\section{Abiotic analyses}

It was established that during all four samples periods, the level of the Paraná River was below that considered to represent floodplain high water conditions (>3.5 m) (Fig. 2). There was a flood between the first

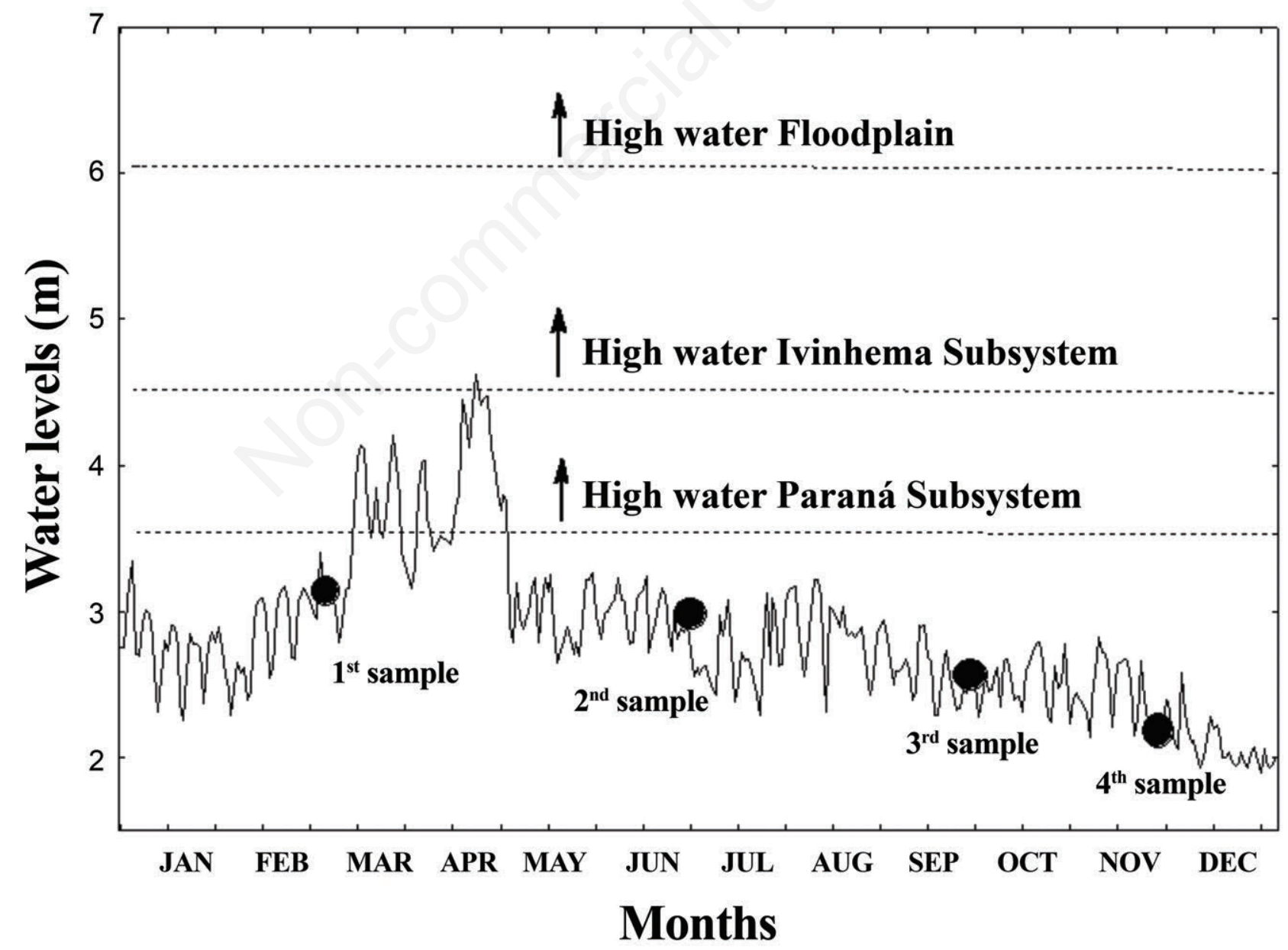

Fig. 2. Daily data of the river level of the River Paraná (m) in 2008, obtained by fluviometric station of Porto Rico-PR, the research base of the NUPELIA. 
and second sampling periods, affecting not only the habitat of the Paraná subsystem $(>3.5 \mathrm{~m})$, but also that of the Ivinhema subsystem $(>4.6 \mathrm{~m})$ (Souza Filho, 2009). The second sample period were taken two months after the floodplain high water period.

Consequently, the four samples periods were accepted as replicates of floodplain low water conditions and the analysis of variance (ANOVA), using the PCA scores of abiotic factors, has confirmed the no significant for axis 1 $(\mathrm{F}=1.46, \mathrm{P}=0.23)$ and for axis $2(\mathrm{~F}=0.40, \mathrm{P}=0.75)$, which demonstrate that it does not have temporal variation between samples.

\section{Biotic analyses}

The species Pristina americana and Aulodrilus pigueti were dominant in almost all habitats of the three subsystems, while Narapa bonettoi dominated mainly lotic habitats as: Paraná River (CE), Ivinhema River (CE and RM) Ipoitã Channel (CE and RM) (Tab. 1).

\section{Habitat structural heterogeneity}

Simple regression analysis between habitat heterogeneity (granulometric+organic matter compositions) and richness of Oligochaeta showed no significance, with $\mathrm{F}$ $(1.142)=3.15 ; \mathrm{P}=0.07$.
However, data distribution formed a triangular pattern, and the test to confirm data dispersion in envelope was significant $(\mathrm{P}($ observed $<$ expected $)=0.04)$. The highest richness of Oligochaeta was found with index value (structural heterogeneity) of 1.98 (standard deviation $=0.77$ ) (Fig. 3).

\section{Organic matter structural heterogeneity}

Simple linear regression did not show relationship between organic matter heterogeneity and richness of Oligochaeta $(\mathrm{F}(1.142)=1.25 ; \mathrm{P}=0.26)$. The dispersion asymmetric test between richness and organic matter heterogeneity does not have significant effect in the triangular pattern $(\mathrm{P}($ observed $>$ expected $)=0.11)($ Fig. 4$)$.

\section{Granulometric structural heterogeneity}

Linear regression analysis showed significant differences $(\mathrm{F}(1.138)=6.21 ; \mathrm{P}=0.01)$ between richness of Oligochaeta and granulometric heterogeneity. The assumption of linearity was observed in both, the intercept and in the slope, which were significant with a negative correlation between richness and granulometric heterogeneity $(\beta=-0.63)$, but the explanation was only $3 \%$. Assumptions of normality and homoscedasticity were not reached. It was verified through the scatter plot of rich-

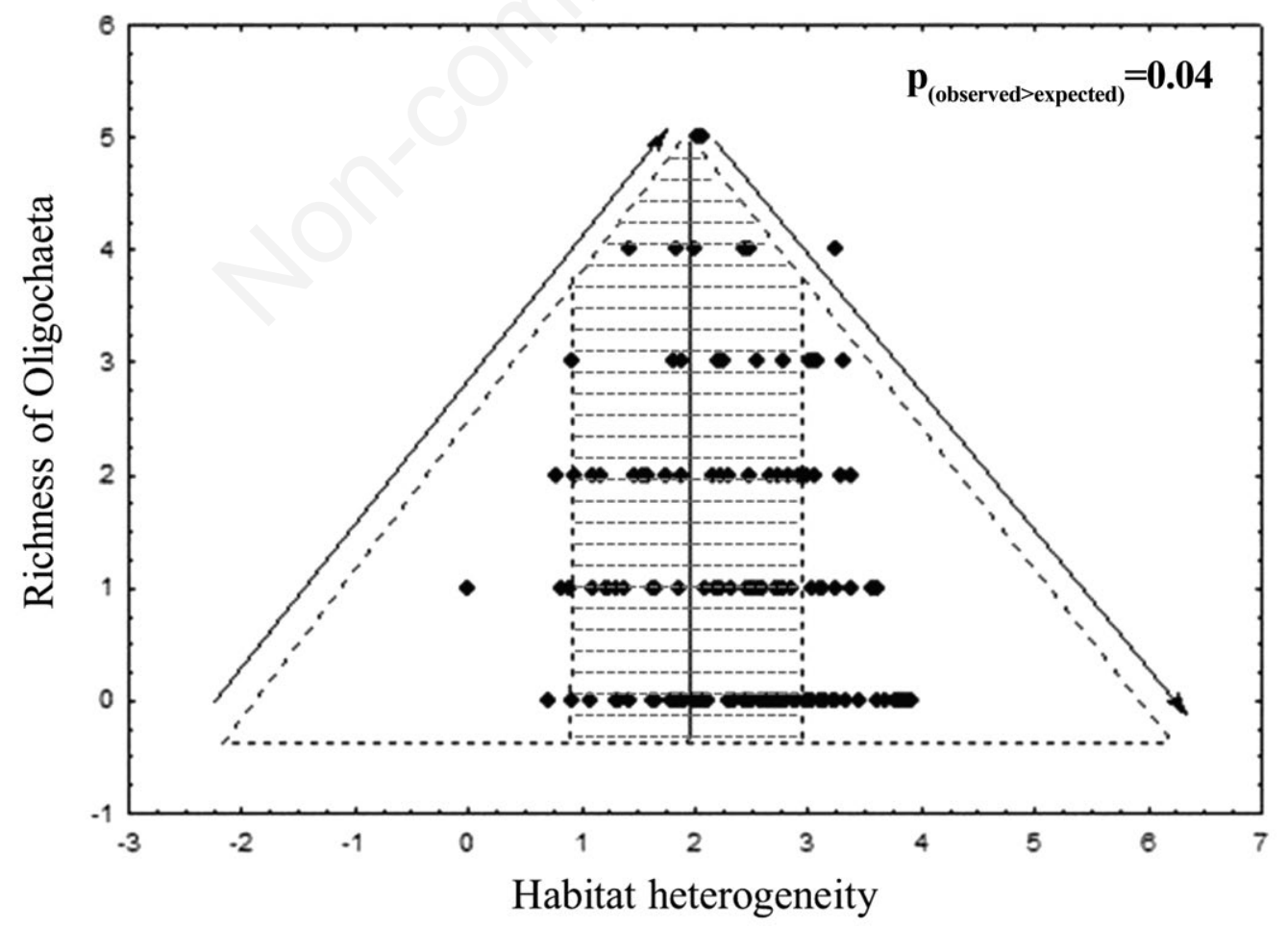

Fig. 3. The relationship between Oligochaeta richnessand habitat heterogeneity (granulometric and organic matter compositions). 
ness of Oligochaeta and granulometric heterogeneity a triangular pattern. Thus, we therefore performed an asymmetric dispersion test. In a total of 5000 randomizations, only 105 habitats (a total of 144 habitats) were allocated outside the envelope restrictions, that indicates the probability of habitats being restricted to an asymmetrical triangular by chance is low $(\mathrm{P}=0.03)$, which states the existence of this triangular pattern. Consequently, richness of Oligochaeta is at its maximum when the granulometric heterogeneity value is 1 (standard deviation $=0.40$ ). This area encompasses about $75 \%$ of the habitats studied (Fig. 5).

\section{DISCUSSION}

The hypothesis of a linear relationship between habitat structural heterogeneity and richness of Oligochaeta was not confirmed, however a triangular pattern distribution was detected, in which there is an increase in richness until certain threshold, and after this, the richness of Oligochaeta decreases.

Studies on habitat structural heterogeneity using aquatic macrophyte have already been performed (Rennie and Jackson, 2005; Thomaz et al., 2008; Mormul et al., 2011), but the use of sediment (granulometric and organic matter compositions) as components of habitat structure are scarce in freshwater environments, despite the fact that a large proportion of aquatic organisms inhabits the sediment, both for reproduction and feeding, such as the zoobenthic community. Many studies emphasized the relationship of granulometric and organic matter compositions on the Oligochaeta distribution (Takeda and Fujita, 2004; Lafont et al., 2007; Behrend et al., 2009) and other benthic organisms (Rae, 2004; Arakaki and Tokeshi, 2005), which demonstrates the importance of these structures of habitat for invertebrate community. Such importance is probably stronger for Oligochaeta, which commonly shows strong relationships with the structures of sediment. However in homogeneous sediments there is dominance of Oligochaeta species related to the predominant structure in this habitat.

Some few species dominated the habitats, such as Narapa bonettoi. This species was highly abundant in center regions of Paraná and Ivinhema Rivers, which is expected due to morphology of lotic sandy sediments (Montanholi-Martins and Takeda, 1999; Takeda et al., 2004; Blettler et al., 2008). Pristina americana is related with high values of organic matter, mud and low oxygen conditions (Montanholi-Martins and Takeda, 1999), thus explaining why this species was only recorded in lentic environments and littoral regions. The species Aulodrilus pigueti is generalist and adapted to a variety of environments and habitats (Behrend et al., 2009; Ragonha et al.,

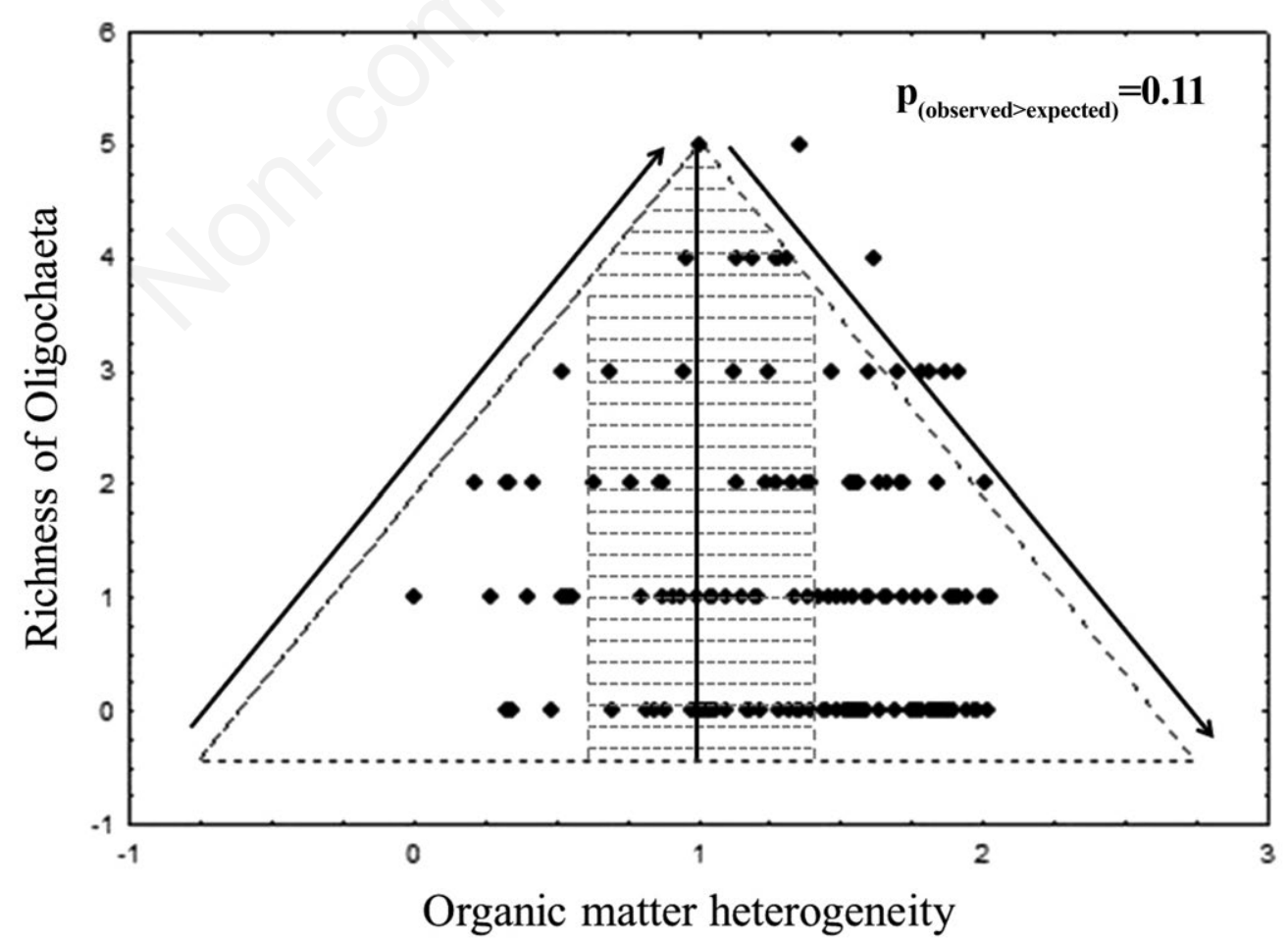

Fig. 4. The relationship between Oligochaeta richness and organic matter heterogeneity. 


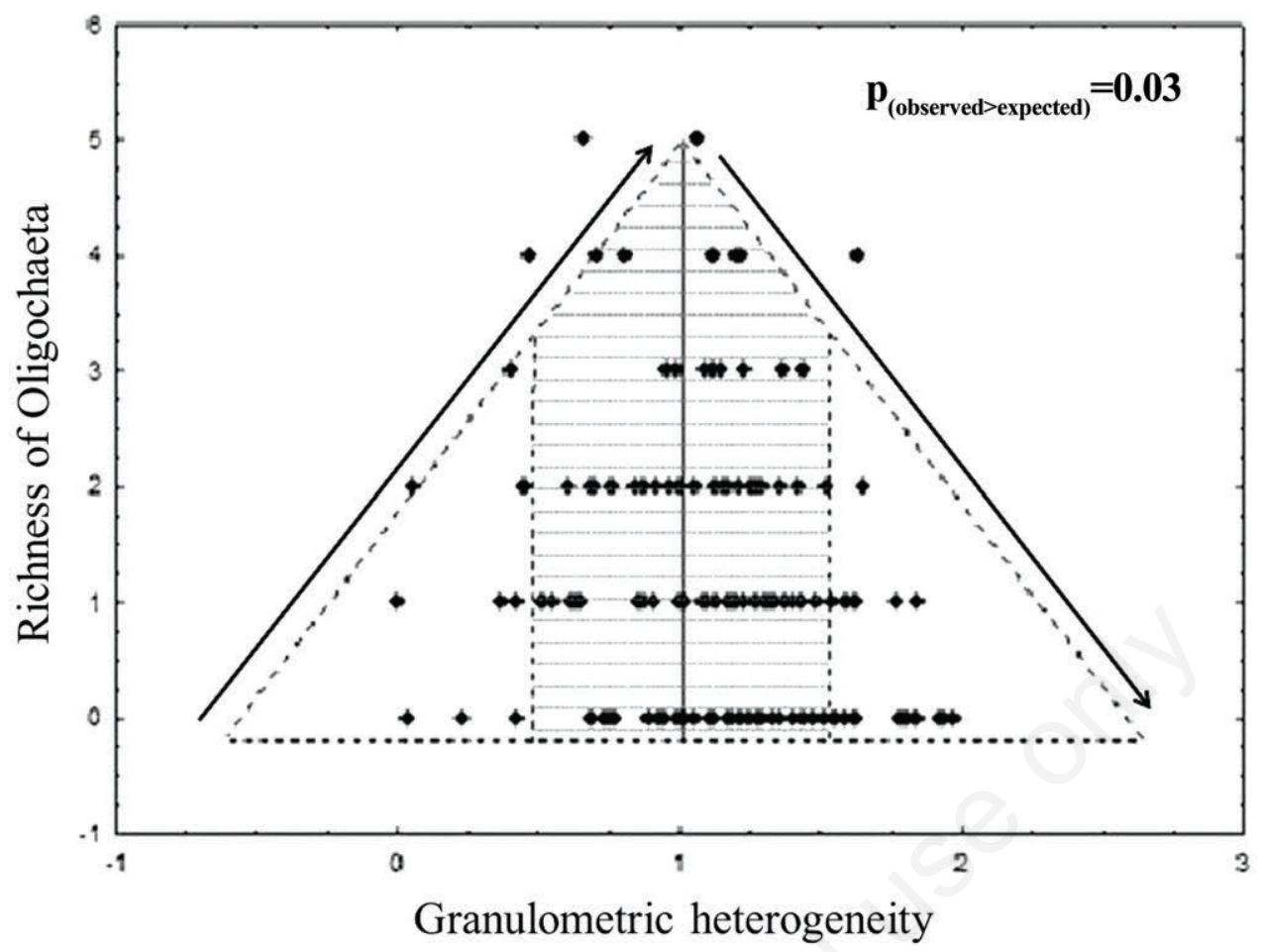

Fig. 5. Relationship between Oligochaeta richness and granulometric heterogeneity.
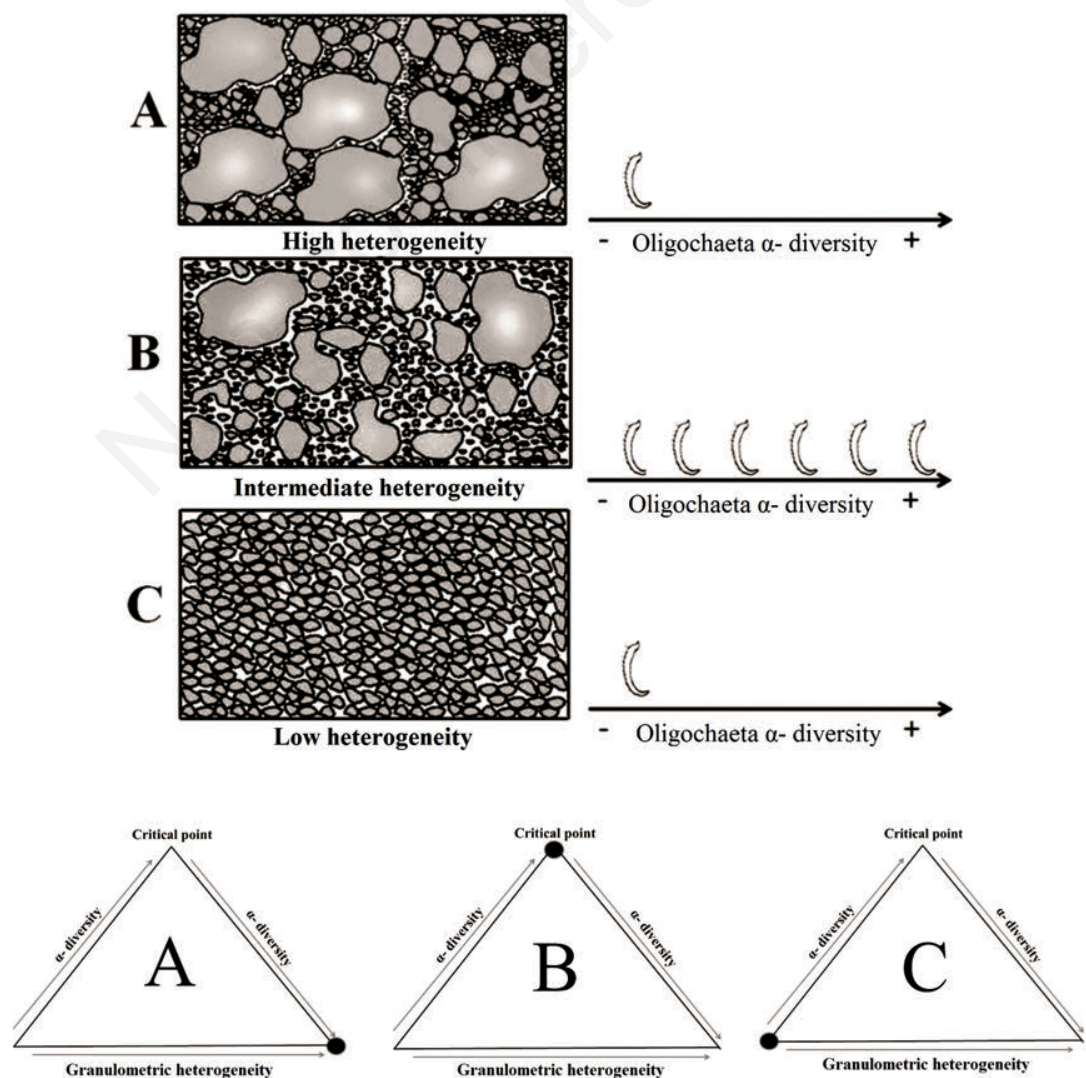

Fig. 6. Theoretical conceptual model of structural heterogeneity of granulometric composition and Oligochaeta $\alpha$ - diversity. A) High heterogeneity. B) Intermediate heterogeneity. C) Low heterogeneity. 


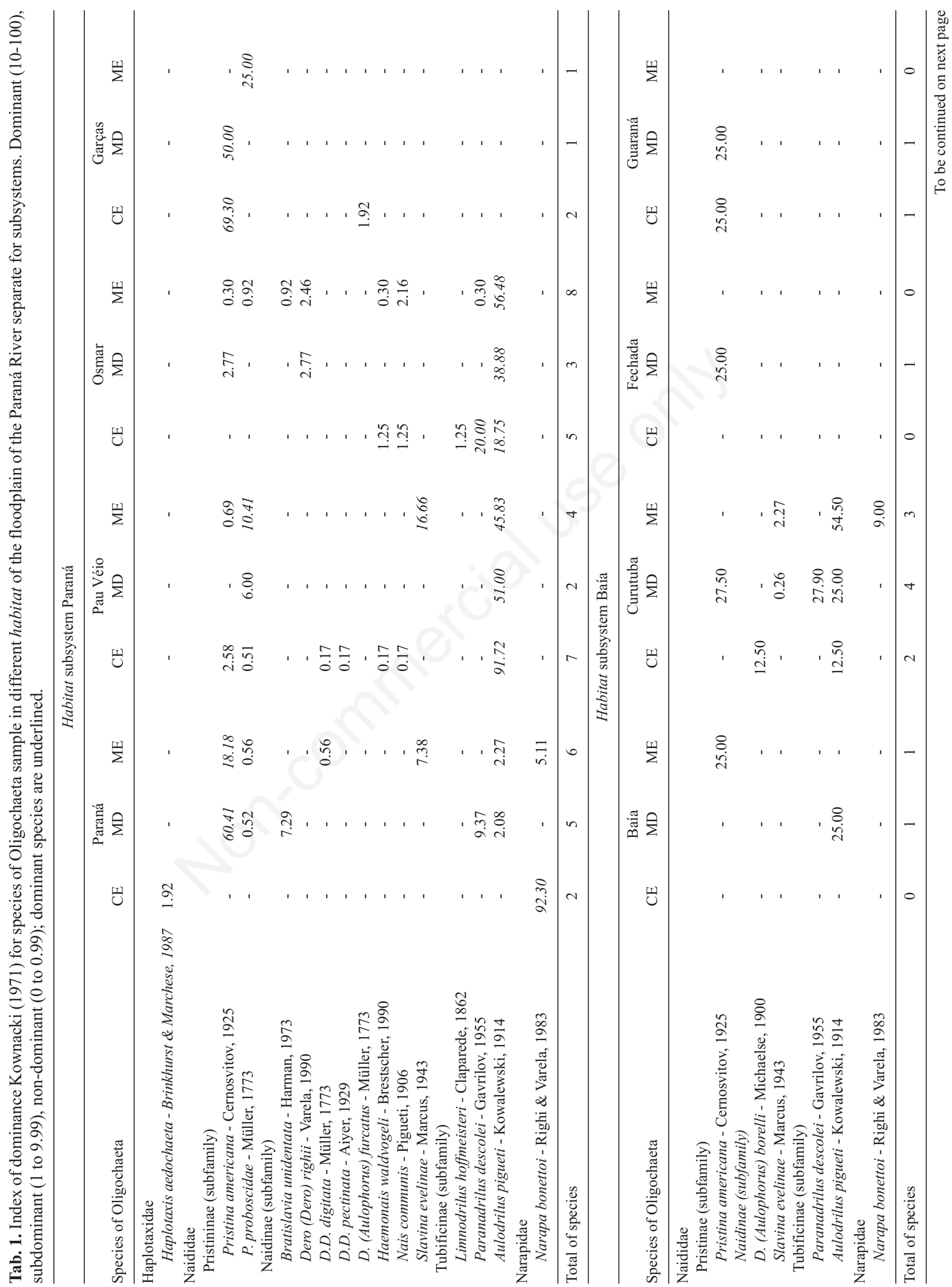




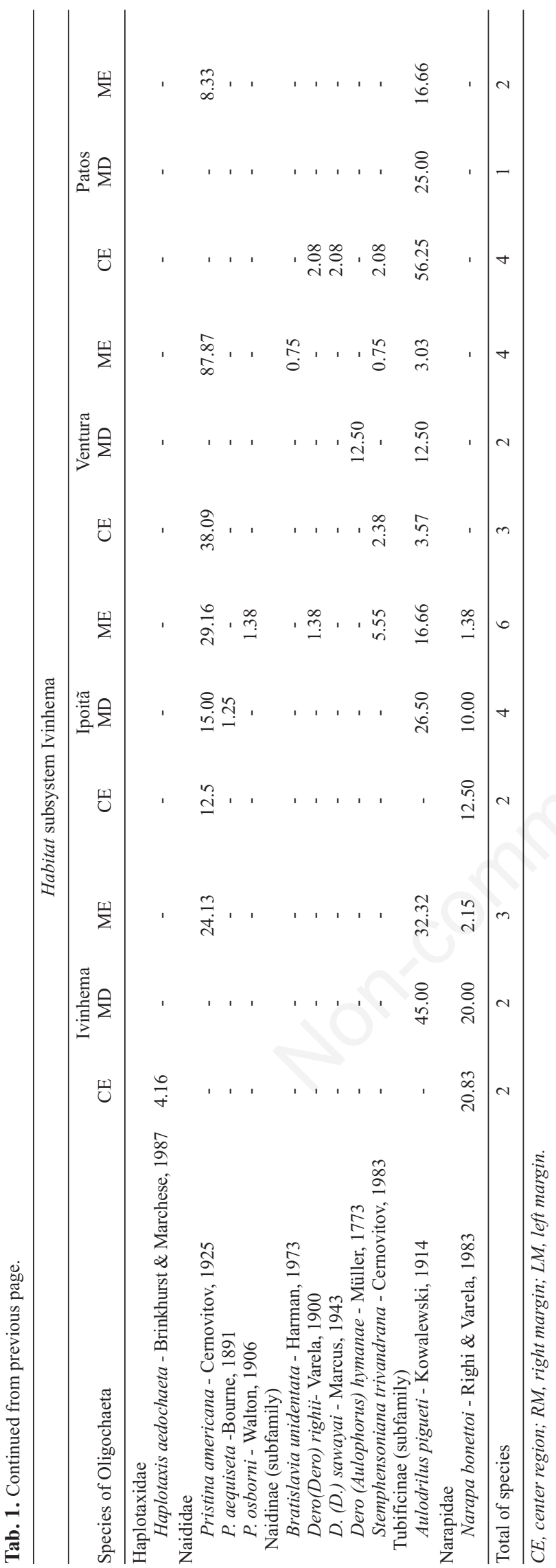

2013) and was registered in the three subsystems and in all types of environments. Although these species dominated the referred habitats the heterogeneity in these habitats favored the colonization of other species rarely recorded, such as Dero (Dero) digitata, Dero (Dero) pectinata, Dero (Dero) sawayai, Dero (Aulophorus) borelli, Pristina aequiseta and Pristina osborni and these results corroborate with studies developed by Rae (2004) and Arakaki and Tokeshi (2005) where habitats with higher heterogeneity of sediment showed higher local diversity of zoobenthos.

Studies of aquatic invertebrate conducted by Taniguchi et al. (2003) and Taniguchi and Tokeshi (2004) found a positive linear correlation with habitat structural heterogeneity and higher values of richness, the same results were found in neotropical floodplains (Higuti et al., 2007; Thomaz et al., 2008). However, no positive linear correlations were detected between habitat structural heterogeneity and richness of Oligochaeta. This result validates those of Thistle et al. (2010) and Tokeshi and Arakaki (2011), in which excessive structure of habitats can result in a harmful habitat to richness. The granulometric structural heterogeneity $(\mathrm{P}<0.05)$ was more important than organic matter structural heterogeneity $(\mathrm{P}>0.05)$, as predicted, with increased of Oligochaeta richness until the index value $=1.0$. Above this value it was observed a progressive decrease of richness of Oligochaeta, since the interstices between larger sediment particles were filled with smaller grains that make the sediment unfavourable to the establishment of Oligochaeta. Consequently, compressed habitats make difficult the movement and colonization by other species, Tokeshi and Arakaki (2011) called it small area of space, which is filled with these smaller particles, and Stevaux and Takeda (2002) demonstrated that interstitial spaces for many invertebrates, especially Oligochaeta are very important, and we elaborated a theoretical conceptual model for a better understanding (Fig. 6).

\section{CONCLUSIONS}

As a result, the heterogeneity of habitat is favorable for benthic organisms until a certain threshold of structuration and after this there were a negative influence of structural heterogeneity of habitats on richness of Oligochaeta. Thus, among the structures that comprise the sediment, the granulometric composition has higher influence than organic matter composition on the richness of Oligochaeta in habitats of floodplain environments.

However, further studies examining the relationship between habitat heterogeneity and richness are needed, mainly with the zoobenthic community which includes several groups like molluscs, crustaceans, annelids and insect larvae with different life strategies. 


\section{REFERENCES}

Agostinho AA, Thomaz SM, Gomes LC, Baltar SLMA, 2007. Influence of the macrophyte Eichhornia azurea on fish assemblage of the Upper Paranà River floodplain (Brazil). Aquat. Ecol. 41:611-619.

Arakaki S, Tokeshi M, 2005. Microhabitat selection in intertidal gobiid fishes: species and size-associated interaction. Mar. Biol. Res. 1:39-47.

Behrend RDL, Fernandes SEP, Fujita DS, Takeda AM, 2009. Eight years of monitoring aquatic Oligochaeta from the Baía and Ivinhema Rivers. Braz. J. Biol. 69:559-571.

Bell SS, McCoy ED, Mushinsky HR, 1991. Habitat structure: the physical arrangement of objects in space. Chapman \& Hall, London: 438 pp.

Blettler M, Amsler M, Ezcurra de Drago I, Marchese M, 2008. Effects of stream hydraulics and other environmental variables on density of Narapa bonettoi (Oligochaeta) in the Paraná River system. River Res. Appl. 24:1124-1140.

Buschbaum C, Dittmann S, Hong JS, Hwang IS, Strasser M, Thiel M, Valdivia N, Yoon SP, Reise K, 2009. Mytilid mussels: global habitat engineers in coastal sediments. Helgoland. Mar. Res. 63:47-58.

Buss DF, Baptista DF, Nessimian JL, Egler M, 2004. Substrate specificity, environmental degradation and disturbance structuring macroinvertebrate assemblages in Neotropical streams. Hydrobiologia 518:179-188.

Brinkhurst RO, Jamieson BMG, 1971. Aquatic Oligochaeta of the world. Oliver and Boyd, Edinburgh.

Brinkhurst RO, Marchese MR, 1991. [Guia para la identificacion de oligoquetos aquáticos continentales de Sud y Centro America]. [Book in Portuguese]. Associacion de Ciencias Naturales del Litoral, Santo Tomé: 207 pp.

Brown BL, 2003. Spatial heterogeneity reduces temporal variability in stream insect communities. Ecol. Lett. 6:316-325.

Costa SS, Melo AS, 2008. Beta diversity in stream macroinvertebrate assemblages: among-site and among-microhabitat components. Hydrobiologia 598:131-138.

Da Rocha CM, Venekey CV, Bezerra TNC, Souza JRB, 2006. Phytal marine nematode assemblages and their relation with the macrophytes structural complexity in a Brazilian tropical rocky beach. Hydrobiologia 553:219-230.

Dibble ED, Thomaz SM, Padial AA, 2006. Spatial complexity measured at a multi-scale in three aquatic plant species. J. Fresh. Ecol. 21:239-247.

Etter RJ, JF Grassle, 1992. Patterns of species diversity in the deep sea as a function of sediment particle size diversity. Nature 360:576-578.

Ezcurra De Drago I, Marchese M, Wantzen KM, 2005. Benthos of a large neotropical river: spacial patterns and species assemblages in the Lower Paraguay and its floodplains. Hydrobiologie 160:347-374.

Gotelli NJ, Entsminger GL, 2004. EcoSim: Null models software for ecology, ver. 7. Acquired Intelligence Inc. \& KeseyBear. Jericho VT 05465.

Harrel SL, Dibble ED, 2001. Factors affecting patterns of juvenile bluegill (Lepomis macrochirus) in vegetated habitats of a Wisconsin Lake. J. Fresh. Ecol. 16:557-580.

Higuti J, Velho LFM, Lansac-Tôha FA, Martens K, 2007. Pleuston communities are buffered from regional flood pulses: The example of ostracods in the Parana River floodplain, Brazil. Freshwater Biol. 52:1930-1943.
Jackson AC, Chapman MG, Underwood AJ, 2008. Ecological interactions in the provision of habitat by urban development: whelks and engineering by oysters on artificial seawalls. Aust. Ecol. 33:307-316.

Kownacki A, 1971. Taxocens of Chironomidae in streams of the Polish High Tatra (Mts). Acta Hydrobiol. 13:439-464.

Lafont M, Grapentine L, Rochfort Q, Marsalek J, Tixier G, Breil $\mathrm{P}, 2007$. Bioassessment of wetweather pollution impacts on fine sediments in urban waters by benthic indices and the sediment quality triad. Water Sci. Technol. 56:13-20.

Li H, Reynolds JF, 1995. On definition and quantification of heterogeneity. Oikos 73:280-284.

Marchese MR, 1987. The ecology of some benthic Oligochaeta from the Paraná River, Argentina. Dev. Hydrob. 155:209-214.

Marchese MR, Ezcurra de Drago I, Drago E, 2002. Benthic macroinvertebrates and physical habitat relationships in the Paraná River-Floodplain system, p. 111-131. In: M. McClain (ed.), The ecohydrology of Southamerican rivers and wetlands. International Association of Hydrological Sciences, Miami, FL, USA.

Magurran A, 1988. Ecological diversity and its measurement. Croom-Helm Ltd.: 172 pp.

McArthur RH, McArthur JW, 1961. On bird species diversity. Ecology 42:594-598.

McCoy ED, Bell SS, 1991. Habitat structure: the evolution and diversification of a complex topic, p. 3-27. In: E.D. McCoy, S.S. Bell and H.R. Mushinsky (eds.), Habitat structure: the physical arrangement of objects in space. Chapman \& Hall, London.

McCune B, Mefford MJ, 1999. PC-ORD - Multivariate analysis of ecological data, ver. 5. MjM Software Design, Gleneden Beach. Accessed: 05 May 2012. Available from: www.garyentsminger.com/ecosim/index.htm

Montanholi-Martins MC, Takeda AM, 2001. Spatial and temporal variations of oligochaetes of the Ivinhema River and Patos Lake in the Upper Paraná River Basin, Brazil. Hydrobiology 463:197-205.

Mormul RP, Thomaz SM, Takeda AM, Behrend RD, 2011. Structural complexity and distance from source habitat determine invertebrate abundance and diversity. Aquat. Ecol. 41:611-619.

Mykra H, Heino J, Okanen J, Muotka T, 2011. The stability-diversity relationship in stream macroinvertebrates: influences of sampling effects and habitat complexity. Freshwater Biol. 56:1122-1132.

Pauleto GM, Velho LFM, Buosi PRB, Brão AFS, Lansac-Tôha FA, Bonecker CC, 2009. Spatial and temporal patterns of ciliate species composition (Protozoa: Ciliophora) in the plankton of the Upper Paraná River floodplain. Braz. J. Biol. 2:517-527.

Rae JG, 2004. The colonization response of lotic chironomid larvae to substrate size and heterogeneity. Hydrobiologia 524:115-124.

Ragonha FH, Chiaramonte JB, Fonte Junior HM, Cunha ER, Benedito E, Takeda AM. 2013. Spatial distribution of aquatic Oligochaeta in Ilha Grande National Park, Brazil. Acta Sci. Univ. Estadual Mar. 35:63-70.

Rennie MD, Jackson LJ, 2005. The influence of habitat complexity on littoral invertebrate distributions: patterns differ in shallow prairie lakes with and without fish. Can. J. Fish Aquat. Sci. 62:2088-2099. 
Righi G, 1984. [Oligochaeta, p. 48]. In: R. Schaden (ed.), [Manual de Identificação de Invertebrados Límicos do Brasil]. [Book in Portuguese]. Conselho Nacional de Desenvolvimento Científico e Tecnológico, Brasília.

Rosenzweig ML, Winakur J, 1969. Population ecology of desert rodent communities: habitats and environmental complexity. Ecology 50:558-572.

Schwindt E, Bortolus A, Iribarne O, 2001. Invasion of a reefbuilder polychaete: direct and indirect impacts on the native benthic community structure. Biol. Invasions 3:137-149.

Souza Filho EE, 2009. Evaluation of the Upper Paraná River discharge controlled by reservoirs. Braz. J. Biol. 69:707-717.

Souza Filho EE, Stevaux JC, 1997. [Geologia e Geomorfologia do complexo rio Baia, Curutuba, Ivinheima, p. 3-47]. In: A.E.A.M. Vazzoler, A.A. Agostinho and N.S. Hahn (eds.), [A Planície de Inundação do Alto rio Paraná]. [Book in Portuguese]. EDUEM, Maringá.

Stevaux, JC, Takeda AM, 2002. Geomorphological processes related to density and variety of zoobenthic community of the upper Paraná River, Brazil. Geomorphologie 129:143-158.

Taniguchi H, Nakano S, Tokeshi M, 2003. Influences of habitat complexity on the diversity and abundance of epiphytic invertebrates on plants. Freshwater Biol. 48:718-728.

Taniguchi H, Tokeshi M, 2004. Effects of habitat complexity on benthic assemblages in a variable environment. Freshwater Biol. 49:1164-1178.
Takeda AM, 1999. Oligochaeta community of alluvial Upper Paraná River, Brazil: spatial and temporal distribution (1987-1988). Hydrobiologia. 412:35-42.

Takeda AM, Fujita DS, 2004. Benthic invertebrates, p. 191208. In: S.M. Thomaz, A.A. Agostinho and N.S. Hahn (eds.), The upper Paraná River and its floodplain. Blackhuys Publ., Leiden.

Tokeshi M, Arakaki S, 2011. Habitat complexity in aquatic systems: fractals and beyond. Hydrobiologia 524:115-124.

Thistle ME, DS Schneider, RS Gregory, NJ Wells, 2010. Fractal measures of habitat structure: maximum densities of juvenile cod occur at intermediate eelgrass complexity. Mar. Ecol. Progr. Ser. 405:39-56.

Thomaz SM, Dibble ED, Evangelista LR, Higuti J, Bini LM, 2008. Influence of aquatic macrophyte habitat complexity on invertebrate abundance and richness in tropical lagoons. Freshwater Biol. 53:358-367.

Thomaz SM, Roberto MC, Lansac Toha FA, Lima AF, Esteves FA, 1992. Limnological characteristics of a sampling station Paraná River and one of the lower Ivinheima River (PR, MS-Brasil). Acta Limnol. Bras. 4:32-51.

Wentworth CK, 1922. A scale of grade and class terms for clastic sediments. J. Geol. 30:377-392.

Whittaker RH, 1960. Vegetation of the Siskiyou Mountains, Oregon and California. Ecol. Monogr. 30:279-338. 